5. Ordonnance N 86-1243 du I decembre 1986 relative a la liberte des prix et de la concurrence // Journal officiel de la Republicue Francaise. 09.12.1986.

DOI https://doi.org/10.30525/978-9934-26-116-9-29

\title{
ЗОБОВ'ЯЗАННЯ ДЕРЖАВИ ЩОДО ЗАХИСТУ ІНФОРМАЦІЙНОЇ ПРИВАТНОСТІ ОСОБИ У СФЕРІ ЗДОРОВ'Я В УМОВАХ КАРАНТИННОГО РЕЖИМУ В УКРАЇНІ: СТАН ТА ПЕРСПЕКТИВИ АДАПТАЦІЇ ДО ЗАКОНОДАВСТВА ЄС
}

\author{
Мех Ю. В. \\ кандидат юридичних наук, дочент, \\ дочент кафедри адміністративного права \\ та адміністративної діяльності Наџіонального юридичного \\ університету імені Ярослава Мудрого \\ м. Харків, Україна
}

\section{Червякова О. Б.}

кандидат юридичних наук, дочент, доиент кафедри адміністративного права

Національного юридичного університету імені Ярослава Мудрого м. Харків, Україна

Оцінка стану виконання положень міжнародних норм щодо правомірності втручання з боку держави в інформаційну приватність особи у сфері здоров'я знаходиться у центрі уваги дослідників у зв'язку із оголошенням пандемії. Карантинний режим вніс багато змін у життя пересічних українських громадян. Особливо це стосується запровадження на законодавчому рівні обробки персональних даних без згоди особи, пов'язаних з ії здоров'ям, а також інших обмежувальних заходів примусового характеру.

Стаття 8 Конвенції про захист прав і основоположних свобод людини (далі - Конвенція) [1] гарантує кожному право на повагу до приватного життя шляхом заборони органам публічної влади втручатися у здійснення цього права. Винятки становлять випадки, коли втручання здіснюється згідно 3 законом і $\epsilon$ необхідним у демократичному сусільстві. Окремий акспект проблеми дотримання 
права на приватність особи становлять персональні дані, які в умовах дії карантину, спричиненого короновірусною хворобою, акумулюються у сфері охорони здоров'я. Аналіз вітчизняного законодавства у сфері захисту інформаційної приватності особи свідчить про його невідповідність міжнародним та європейським стандартам в цій царині. Зазначине обумовлює потребу аналізу законодавства України в цій сфері з огляду на дотримання вимог його «якості», а також «якості» персональних даних.

Умови, при дотриманні яких держава може втручатися у здійснення охоронюваного права шляхом його обмеження, викладені у пункті 2 ст. 8 Конвенції. Так, обмеження допустимі, якщо : 1) вони передбачені законом; 2) необхідні у демократичному суспільстві для захисту однієї з цілей, передбачених у пункті 2 ст.8. У практиці ССПЛ оцінка дотримання державою зазначених умов здійснюється за такими критеріями : «законність», «правомірна мета», «необхідність». При цьому підставою для втручання $є$ запровадження певного правового режиму, який регулює певну сферу діяльності, у тому числі правила, встановлені відповідним органом шляхом делегування повноважень із законотворчості [2]. Розглянемо ці питання щодо права особи на приватність персональних даних у сфері здоров'я в умовах дії в Україні карантину, спрямованого на запобігання поширенню короновірусної хвороби COVID-19.

Право на захист персональних даних фізичних осіб під час їх опрацювання $\epsilon$ фундаментальним правом. Це випливає зі вступної частини Регламенту 2016/679, ст.8(1) Хартії фундаментальних прав СС та ст. 16(1) Договору про функціонування Свропейського Союзу, якими встановлено, що кожна особа має право на захист своїх персональних даних (параграф (1) Вступу до Регламенту Свропейського Парламенту i Ради ЄС 2016/679 від 27.04.2016 р. про захист фізичних осіб у зв'язку 3 опрацюванням персональних даних і про вільний рух таких даних (далі - Регламент 2016/679) [3]. Зазначене право не є абсолютним : воно повинно розглядатися в зв'язку з його функцією у суспільстві та бути збалансовним 3 іншими фундаментальними правами згідно 3 принципом пропорційности (параграф (5) Вступу до Регламенту 2016/679). Так, аналіз положень Регламенту 2016/679 дозволяе зробити висновок, що відступ від заборони на опрацювання такої спеціальної категорії персональних даних, як стан здоров'я може мати місце за наявності таких підстав та умов : 1) оброблятися для цілей здоров'я, таких, як охорона суспільного здоров'я, управління послугами в сфері охорони здоров'я (параграф (45) Вступу до Регламенту 2016/679); 2) грунтуватися на важливих підставах суспільного інтересу та 
життєво-важливих цілей, у тому числі моніторингу епідемій та їхнього розповсюдження (параграф (46) Вступу до Регламенту 2016/679); 3) забезпечення безпеки в галузі охорони здоров'я, цілей моніторингу та попередження, запобігання або контролю за інфекційними захворюваннями та іншими серйозними загрозами для здоров'я (параграф (52) Вступу до Регламенту 2016/679); 4) необхідність здійснення для цілей, пов'язаних з охороною здоров'я, лише якщо необхідно досягти таких цілей в інтересах фізичних осіб та суспільства в цілому, зокрема, в контексті управління послугами та системами охорони здоров'я для цілі контролю якості (параграф (53) Вступу до Регламенту 2016/679).

В Регламенті також наголошується, що в цілях охорони суспільних інтересів у галузях охорони суспільного здоров'я, опрацювання персональних даних може здійснюватися без згоди його суб'єкта. При цьому «суспільне здоров'я» необхідно тлумачити як «усі елементи, що стосуються здоров'я, а саме стан здоров'я, потребу у послугах 3 охорони здоров'я, у тому числі захворюваність і недієздатність, визначальні чинники, що впливають на стан здоров'я, тощо (параграф (54) Вступу до Регламенту 2016/679).

На нашу думку, важливою правовою гарантією забезпечення права особи на захист персональних даних $\epsilon$ чітке врегулювання меж втручання з боку держави у приватність особи, а також встановлення на законодавчому рівні строків зберігання персональних даних. Зокрема, ст.5 Конвенції про захист осіб у зв'язку з автоматизованою обробкою персональних даних ( далі - Конвенція 108) [4] наголошує, що вони мають зберігатись у формі, яка дозволяє ідентифікацію суб'єктів даних не довше, ніж це необхідно для мети, для якої такі дані зберігаються. До принципів опрацювання персональних даних ст. 5 Регламенту 2016/679 відносить, зокрема, законність, правомірність і прозорість; визначення чітких і законних цілей; достатність і обмеженість даних мірою необхідності в них з огляду на цілі опрацювання («мінімізація даних»); збереження у формі, що дозволяє ідентифікацію суб'єктів даних не довше, ніж це є необхідним для цілей їхнього опрацювання, зокрема, суспільного інтересу («обмеження зберігання»). В будь-якому разі законодавчий інструмент має містити положення й щодо періодів зберігання персональних даних та застосовних гарантій 3 огляду на специфіку, обсяг та цілі опрацювання чи категорії опрацювання (параграф 2 (f) ст. 23 Регламенту 2016/679).

Втім, зазначені положення Регламенту 2016/679 у сфері охорони здоров'я до теперішнього часу не знайшли свого закріплення у законодавстві України. Так, Прикінцевими та перехідними положеннями Закону від 13.04.2020 р. «Про внесення змін до Закону України «Про захист населення від інфекційних хвороб» щодо 
запобігання поширенню коронавірусної хвороби (COVID-19) дозволено обробку персональних даних без згоди особи, зокрема, даних, що стосуються стану здоров'я, місця госпіталізації або самоізоляції, прізвища, імені, по батькові, дати народження, місця проживання, роботи (навчання), з метою протидії поширенню коронавірусної хвороби (COVID-19), в порядку, визначеному в рішенні про встановлення карантину, за умови використання таких даних виключно з метою здійснення протиепідемчних заходів. Такі дані підлягають знеособленню, а у разі неможливості - знищенню протягом 30 днів після закінчення періоду встановлення карантину [5]. Зрозуміло, що на початку запровадження карантину важко було передбачити його терміни, втім після більш ніж річної його дії цілком обгрунтовано постає питання про необхідність знеособлення або знищення накопичених персональних даних у відповідних базах та реєстрах, зокрема щодо осіб, які перебували на самоізоляції чи в обсервації. Зазначимо, що з часу запровадження в Україні карантинного режиму понад 20 разів змінювалися і доповнювалися «правила гри»з огляду на встановлення обмежень і заборон в цій сфері. Таке нестабільне регулювання відносин не дає підстав стверджувати про «якісне законодавство» 3 передбачуваними наслідками. Варто згадати і практику Свропейського Суду з прав людини, який визначив два критерія, яким має відповідати норма права 3 тим, щоб вважатися «якісним» законом. По-перше, норма має бути належним чином доступна : особи повинні мати відповідно до обставин можливість орієнтуватися в тому, які правові норми застосовуються у конкретному випадку. По-друге, норма права не може вважатися «законом», якщо вона не сформульована $з$ достатнім ступенем точності, що дозволяє громадянинові узгодити з нею свою поведінку [6].

Подальша європеїзація України обумовлює актуальність питання про гармоніацію iii законодавства із законодавством ЄС. Нажаль, як в цілому, так і з окремих питань національне законодавство в сфері захисту персональних даних не відповідає європейським настановам щодо чіткого окреслення меж втручання держави у приватне життя фізичних осіб. Тож зовсм не випадково у Національній стратегії у сфері прав людини, затвердженої Указом Президента України від 24.05 .2021 р. [7] серед проблем, які заважать реалізації права особи на приватність, названо неузгодженість вітчизняного законодавства про захист персональних даних з європейськими стандартами, відсутність дієвого інституційного механізму незалежного контролю в цій сфері, існування надмірних баз персональних даних тощо. Тому нагальною потребою є приведення законодавства України в цій царині, у тому числі й у медичній сфері, у відповідність із міжнародними зобов'язаннями України. 


\title{
Література:
}

1. Відомості Верховної Ради Украӥни.1997.№ 40.Ст.263.

2. Barthold v.Germany, A 90 (1985) 7 EHRR 383, *45-46.

3. Офіиійний вісник Свропейського Союзу.L 119/1.04.05-2016.

4. Відомості Верховної Ради Украӥни.2010.№ 46.Ст.542.

5. https://zakon.rada.gov.ua>530-20.

6. A 30 (1979), 2 EHRR 245,*49 PC.

7. https://zakon.rada.gov.ua>.

\section{DOI https://doi.org/10.30525/978-9934-26-116-9-30}

\section{ПРОБЛЕМИ РЕГУЛЮВАННЯ ПРАВА ГРОМАДЯН НА ОФІЦІЙНУ ІНФОРМАЦІЮ}

\author{
Погорілецька А. В. \\ старший викладач кафедри кримінально-правових дисииплін \\ Криворізького факультету Національного університету \\ «Одеська юридична академія» \\ м. Кривий Ріг, Дніпропетровська область, Україна
}

Правова направленість українського суспільства до європейських стандартів та цінностей ставить перед державними органами влади України чіткі вимоги до законотворчості і стратегій пошуку вдосконалення вже існуючих правових норм. При цьому слід відзначити, що основна діяльність української держави сьогодні повинна бути направлена на створення дієвих механізмів, направлених на захист прав $\mathrm{i}$ основних свобод людини. Вочевидь, що право громадян на інформацію відноситься до одного з базових прав людини, а право особи на отримання інформації від органів державної влади та місцевого самоврядування потребує детального дослідження та правової регламентації, яка забезпечить інформаційні права і свободи людини. Саме державою повинні створюватись дієві стратегії реформування державного управління, спрямовані на утворення нового формату регламентації та регулювання інформаційних відносин з питань права громадян на офіційну інформацію.

Офіційна інформація являється однією із правових гарантій держави на відкритість і прозорість своєї діяльності по відношенню до суспільства в цілому, не залежно від громадянства особи. В свою чергу, 